\title{
Impact of Development on deforestation in Sri Lanka: An analytical study
}

\author{
${ }^{1}$ Ravindra Kariyawasam, K.M.H (PhD Student), ${ }^{2}$ Chinthak Rajapakse \\ ${ }^{1,2}$ Centre for Environment and Nature study, 1149, Kotte Road, Rajagiriya, Sri Lanka.
}

Abstract: The research based on deforestation of Sri Lanka. Sri Lankan government has being published 20112030 National physical plane policy (National physical plane, 2002). The government is conducting developments base on national physical plane. This research paper is concerned about the developments are conducting and those effects in destruction of Forest cover in the country.

\section{Introduction}

Sri Lanka is an island nation with a total land area of $65,525 \mathrm{~km} 2$, located in the Indian Ocean just off the southeastern tip of India,Sri Lanka is one of bio diversity hotspot (Conservation International, 2011) .Most developments are destroying natural environment in Sri Lanka. While this development moves forward, environmental conditions are getting worse. This research paper is based on development and deforestation in Sri Lanka.

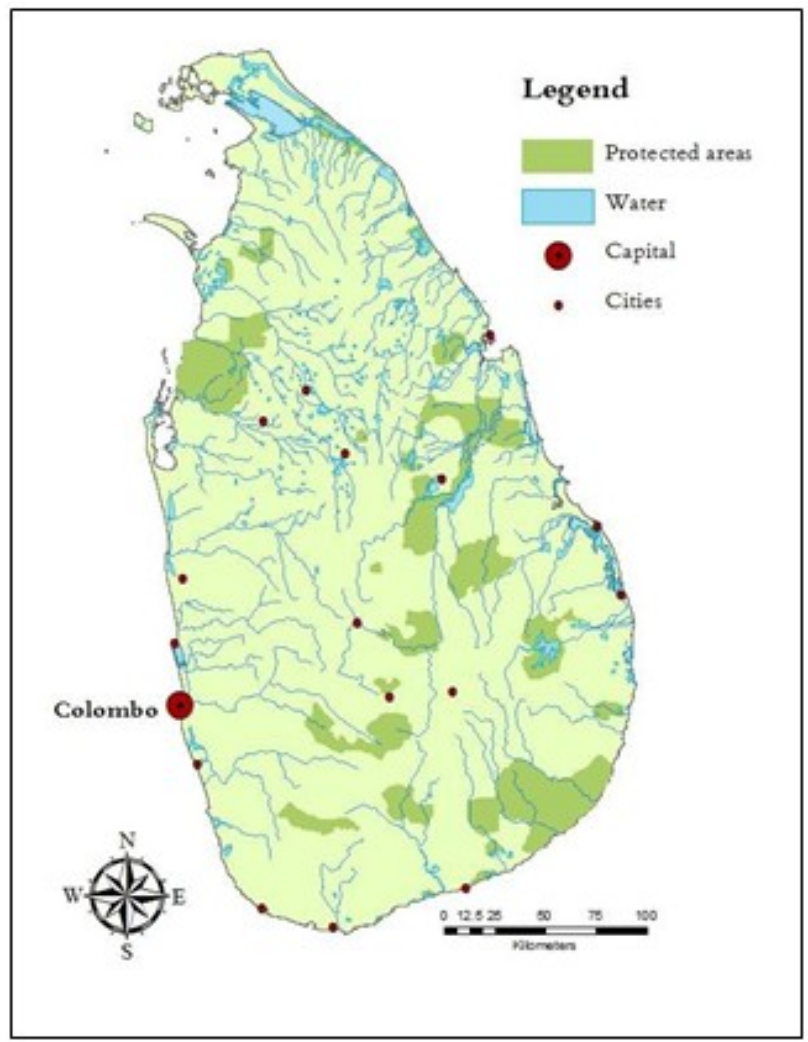

Figure 1: Shows the location of Sri Lanka (above) and an enlargement of the island (Lindström,2011)

The Sri Lanka southwestern parts receive most rainfall, especially between May and October, when the south-west monsoon strikes the island. The north of the region and most of the eastern part comprise the dry zone with Hambanthota and manner. Mountainous region are situated in the south-central part of Sri Lanka ; the majority of the island consists in lowland with an average annual temperature of $27^{\circ} \mathrm{C}$. Due to the elevation, the central hill country has an average temperature around $10^{\circ} \mathrm{C}$ colder than the lowland. The highest point, mountainPidurutalagala, reaches 2524 meters above sea level 


\section{Methodology of Research}

Researcher carried out field visitsand conducted observationsconcerndeforestation in Sri Lanka. He photographed also the affected areas for record purposes. The researcher is involved to collect data when he was working voluntarily in the environment field

Literary reviewsare selected as a research methodology to collect secondary data for this research. Magazines, scientific journals, books, newspapers and other journal areused to collect the secondary data.

\subsection{Deforestation in Sri Lanka}

During the colonial period in Sri Lanka were cut down trees and forest cover to develop commercial agriculture. Between 1505 and 1945 the Dutch, portages and English colonizationhad accelerated deforestation process in the Country.(Mongabay , 2014 )

After independence timber production get increased, with the aim to fuel the economic and industrial development of the new nation. The government established ply-wood companies and other timber cooperations that heavily contributed to the continued deforestation through intensive logging, especially in the wet-zone. While the decades that followed, until today, witnessed a threefold population increase, the demand for Development project such as housingand commercialagricultural destroying the forest. (VitaranaK.M ,1997)

Sri Lanka's natural forest cover has dwindled from $80 \%$ to less than $16 \%$ over the last 100 years. At the end of the 19th century, more than $80 \%$ of the country was covered by forest; at the beginning of the 20 th century this rate had been reduced to $70 \%$ andin 1950 only half of the land area was forested. In summary by the beginning of the 1990s forest cover remained less than a quarter of the country.(Bogawattha,1999) .

According to government, forest cover has shrunk back a further $5 \%$ over the 1990s (NPPD, 2002).As we move into the 21 st century, the threats to natural forest persist unabated and the national forest estate continue to be rapidly eroded.

After 1970 huge development scheme called "the MahaweliIrrigation Project" was implemented, with the main objective to irrigate large areas of the dry-zone in the northeast and make these soils more suitable for agriculture, especially for the production of rice. This project mainly implemented development in the jungle areas. (Ranasingha, D.M.S 1998)

Many development projects ware accelerated deforestations in Sri Lanka and it has badly impact to reduce forest cover to $20 \%$ in 2007 . Following figures are showing details about hugeDeforestation in the country.

\begin{tabular}{|l|l|l|}
\hline Year & $\begin{array}{l}\text { Increasing human } \\
\text { populating }\end{array}$ & Deforestation in country \\
\hline 1881 & $2.4 \%$ & $82 \%$ \\
\hline 1900 & $2.7 \%$ & $70 \%$ \\
\hline 1956 & $11.2 \%$ & $44 \%$ \\
\hline 1983 & $15.1 \%$ & $27 \%$ \\
\hline 1992 & $17.4 \%$ & $24 \%$ \\
\hline 1998 & $18.1 \%$ & $20 \%$ \\
\hline 2002 & $19.2 \%$ & $18 \%$ \\
\hline 2007 & $19.4 \%$ & $17 \%$ \\
\hline
\end{tabular}

Figure .03 Deforestation rate in Sri Lanka (Natural environment of Sri Lanka, 2008)

According to Kariyawasam.R ,(2011),under the commercial agricultural projects, in 2011,both Dole Company and CIC company had deforested $65525 \mathrm{hq}$ of forest area in the regions ofButtala, Lunugamwehera,Somawathiya National Park and Chunnakkadu Sanctuary.

Both agriculture companies were involved to cultivated Cavendish banana after clearing forest cover in Sri Lanka. This kind of situation has been badly impacted to reduce forest cover in Sri Lanka and it has being badly impacted to bio diversity in the county. (Wild reach, 2011).

According to Centre For environment and nature Studies, Road Development projects ware stated through Sinharaja World heritage Site area of Imbulakanad to Suriyakanada and Lanakgama to Deniyaya, (The Island ,2011).Those road development project's has been effected to reduce primary and secondary forest cover in Sri Lanka.

World Food and Agriculture Organization (FAO) showing details including the countries of Bangladesh, Bhutan, Brunei, Cambodia, East Timor, India, Indonesia, Laos, Malaysia, Maldives, Myanmar, Nepal, Pakistan, Philippines, Singapore, Sri Lanka, Thailand, and Vietnam. Each of them lost about $1 \%$ of its forests each year. (Global Forest assessment, 2005). According to FAO, from the end of 2005 Sri Lanka become the fourth worst deforestation in primary forest among that country's. 
Worst deforestation rate of primary forests, 2000-2005. All countries.

\begin{tabular}{|l|l|l|}
\hline No & Country & Total Primary Forest \\
\hline 01 & Nigeria & $55.7 \%$ \\
\hline 02 & Viat Nam & $54.5 \%$ \\
\hline 03 & Cambodia & $29.4 \%$ \\
\hline 04 & Sri Lanka & $15.2 \%$ \\
\hline 05 & Malani & $14.9 \%$ \\
\hline 06 & Indonasia & $12.9 \%$ \\
\hline 07 & North Korea & $9.3 \%$ \\
\hline 08 & Napal & $9.1 \%$ \\
\hline 09 & Panama & $6.7 \%$ \\
\hline 10 & Guatemala & $6.4 \%$ \\
\hline
\end{tabular}

Figar.4 All area figures are in hectares (Global forest assessment, 2005).

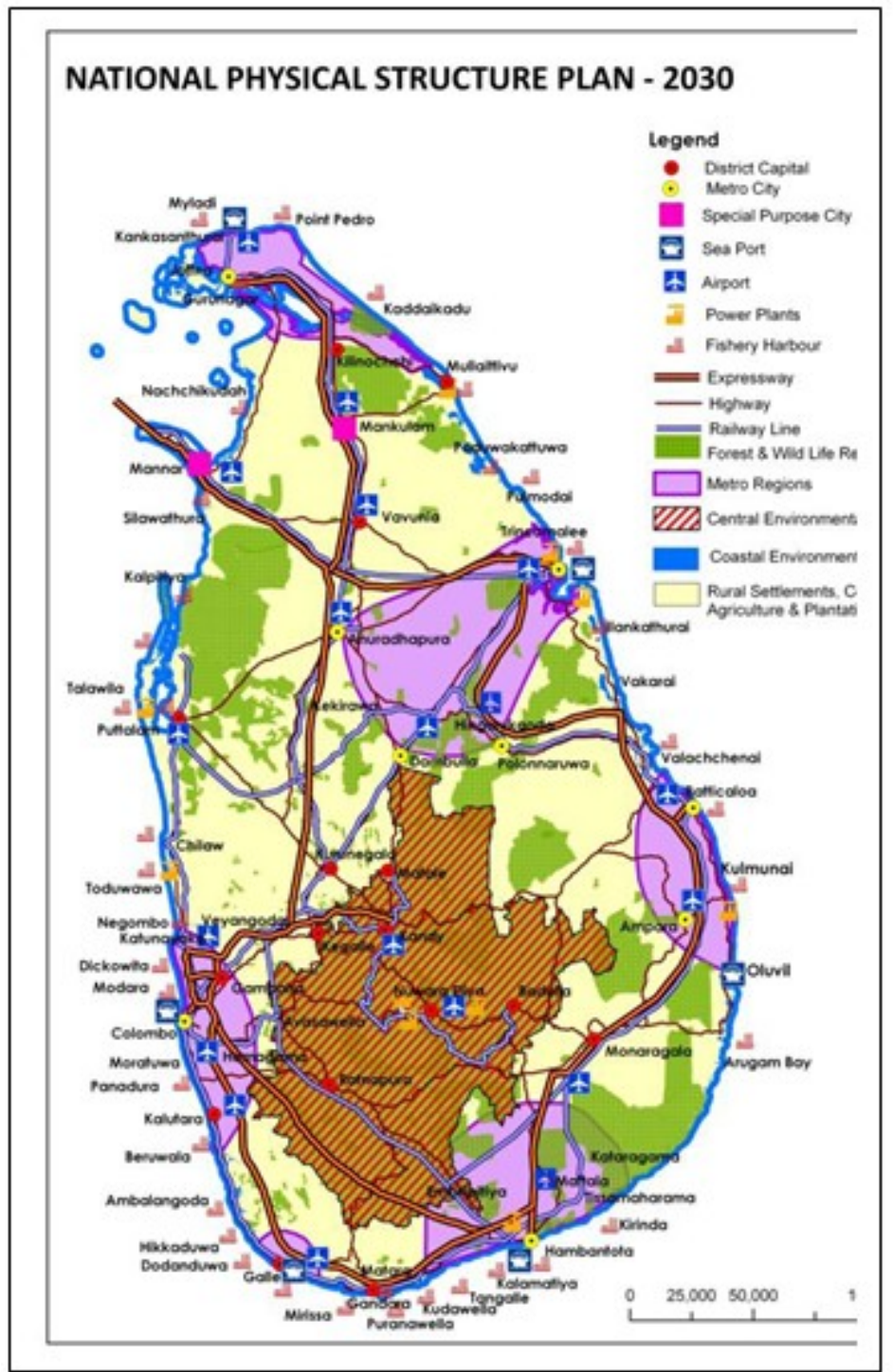




\section{National physical development plane and deforestations in Sri Lanka.}

For the period 2011-2030, Sri Lanka Government has being introduced anational physical planefor physical development in Sri Lanka. So the government contuses to build $1000 \mathrm{~km}$ highways around the island. Six metro regions are going to build before theend of 2030.

The main government projects are concerned tourism developments. It is planned to develop new tourism areas in Kalpitiya, Mannar, Jaffna and Kucchaweli. Ocean based tourism areas, beach based tourism areas, Historical and traditional tourism areas going to develop island wide.(National physical plane in Sri Lanka 2011-2030).

Indigenous medicine and medical tourism projects are going to build in base on Bibilaand Nilgala forest area.The Development projects are going on in the forest of Nilgala. Due to starting the development 5000 acres of forest has being destroyed in 2014(DailyNews, 2014).

The National physical plan will terminate to 19 th airport including 10 domestic airport end of 2030.one international airport recently opened in Matthala. it has being built in bird centaury .the sanctuary has destroyed due to constructions .(Leon Benger, 2013).

The government has being started commercial agriculture projects Under the Department inAgriculture inAnuradapura,Madawachiya,Vauniya and Monaragala areas.
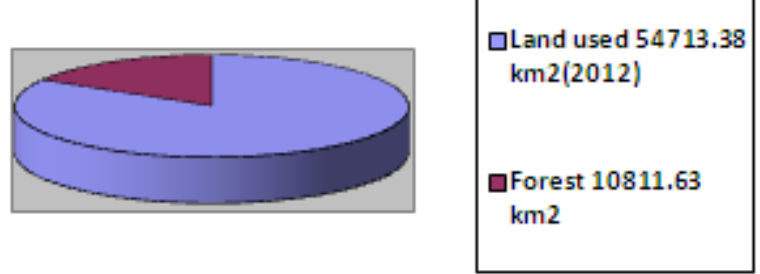

The used land and remaining forest In Sri Lanka.

They cultivate fruit, vegetable, peanut, green gram, cashew, sugar cane, frame oil and commercial forest plantation. (National Physical Plane 2011-2030)

39 forest area has being threaten by physical development in the country, including with Sinharaja , Adams peak, Knuckles world heritage. Wilapatthu, yalanataanlaparak, sanctuary, wetlanad and other small forest patches. (Kariyawasam .R ,2013).

\section{Discussions and Conclusions'}

Sri Lanka is one of theBio Diversity hot spot (IUCN, 2014). At the same time, mega developments are going on. The National Physical plane development projects are being implemented all over the Country. In this situation forest covers are being goingdown.

The data showing that at the end of 2007, it remained only the $17 \%$ of forest cover in the Country, (Natural Environment of Sri Lanka, 2008).Due to implementing physical development projects such as $1000 \mathrm{~km}$ of highway, Mega City and other developments Projects removed many trees and forest cover from earth of Sri Lanka.

Road constructions has being started throughSinharajaya primary forest ( GanegodaAriyarathna, 2013) .At the same time, another road development project is going on through Soragune Primary forest .(The Nation, 2013)

Tourism development and some other development projects are going on, such as inWillpattuwa National Park and into the other national parks. The forest covers are going down day by day, year by year. If this high deforestation will go on, it estimated that at the end of 2030, lessthan $10 \%$ of forest cover will remain in Sri Lanka).

\section{Bibliography}

[1]. AriyarathnaGanegoda,(2011),Construction Of Road Across SinharajaHalted ,CeyonToday ,Colombo ,Sri Lanka

[2]. Bogahawatta, C.(1999), Sri Lanka-Forestry Policy, Non-Timber Forest Products And The Rural Economy In The Wet Zone Forests Environment And Economics Programe For Southeast Asia(EEPSEA)Research Report,Ottawa.

[3]. Bringer Leon ,(2013), Water Holes Around MattalaClosed To Keep Away Birds And Animals, Sunday Times ,Http:/Www.Sundaytimes.Lk/130407/News/Water-Holes-Around-Mattala-Closed-To-Keep-Away-Birds-And-Animals40385.Html.

[4]. CI Fact, (2011), Conservation International, Sri Lanka.

[5]. Daily News , (2014),Herbal Forest Destroyed ,Http://Www.Dailynews.Lk/Local/Herbal-Forest-Destroyed.

[6]. IUCN,(2014).World Bio diversity hotspot, www.IUCN.com

[7]. Lindstrom Sara, (2011), Tropical Deforestation In Sri Lanka A Minor Field Study Investigating The Impact Of Small Scale Farmers, University Of Gothenburg, Sweden

[8]. Mongabay .(2014), Rainforests.Mongabay.Com/20srilanka.Htm. 
[9]. National Physical Plane Policy, (2002), National Physical Planning Department, Ministry Of Western Region, Colombo,

[10]. Ranasingha D.M.S ,(1998), Environment concern in the accelerated mahaweli project, Department of Forestry and Environment Science, University of Sri Jayawardanapura,Sri Lanka.

[11]. SivanathenVijayaluxmi, (2013)Environmentalists See No 'Birdie' In Golf Project, The Nation, Sri Lanka

[12]. The Island (2011), Govt. Encouraging Businessmen To Destroy Forests - Environmentalists, Colombo.

[13]. Vitarana. K.M,(1997), Forestry Sector Master Plan And Ngos, The Island,Colombo Sri Lanka.

[14]. William .J (2006), Ecological Censes Techniques', Cambridge University Press.

[15]. Http://Wildreach.Blogspot.Com/2011/08/Govt-Encouraging-Businessmen-To-Destroy.Html). 